\title{
Anxiety and stress in miscarriage
}

\begin{abstract}
Miscarriage is defined as an adverse and unexpected termination of pregnancy before the completion of $22^{\text {nd }}$ week of gestation. Currently, abortion is the most common early reproductive failure. In Poland, more than 40000 pregnant women a year lose pregnancy due to various reasons. There are many reports in literature on the risk of somatic consequences of miscarriage, while extra-somatic complications resulting from exposure to the strong influence of anxiety and stress, such as, for example: depression and psychosomatic disorders have not been paid too much attention to, yet. Abortion is accompanied by stress and a lot of negative emotions, such as anxiety. They may intensify both due to hospitalization and the need to implement treatment. These negative emotions destroy cognitive power of women, depriving them of their confidence, they can exacerbate the sense of danger, lead to stress and hinder treatment.
\end{abstract}

Keywords: miscarriage, emotions, anxiety, stress.

DOI: $10.1515 /$ pjph-2015-0046

\section{INTRODUCTION}

Pregnancy causes a number of changes to the female body, both of a biological and emotional nature, mostly related to entering a new role in life. An unexpected termination of pregnancy before the $22^{\text {nd }}$ week of its duration, as a result of miscarriage, is the most common early reproductive failure [1]. The abortion process is loaded with stress and negative emotions, further exacerbated by the need for treatment and hospitalization. Too little attention in clinical practice is paid to abortion perceived as a traumatic event, causing stress and anxiety $[1,2]$.

Due to the fact that abortion is an emergency, it is clear that it is impossible to prepare for it [2]. In case the medical staff provide no support to the women laden with psychological stress associated with miscarriage, some further longterm consequences, like disturbances in the area of health and psycho-social functioning may occur [3].

\section{EPIDEMIOLOGY}

Around 15 to $20 \%$ of human pregnancies are lost in Poland as a result of miscarriage. Some 41000 women experience a miscarriage every year. About $80 \%$ of abortions take place before the 12th week of gestation is finished $[3,4]$. Experiencing one abortion increases the risk of subsequent pregnancy losses. The observations made with the use of assisted reproduction techniques show that over 50\% of fertilized ova are not implanted. Furthermore, the studies demonstrated that up to $60 \%$ of human pregnancies after implantation may be lost before any clinical symptoms of pregnancy appear [5].

\section{ANXIETY AND STRESS IN MISCARRIAGE}

Today, it is believed that emotions and emotional experience create emotionality and a balance in the world of emotions guarantees maintaining health [6-9]. According to literature, the word emotion has two meanings: the first is characterized by emotions as inter-individual tendency to live, that is, as feelings, while the other focuses on human behavior in a given situation [10-12]. The anxiety and stress accompanying a pregnancy loss significantly affect the behavior of women, interfere with the proper functioning of psychosocial and makes the healing process more complicated [10]. Health care providers should pay attention to the fact that there is a need for individual assessment of every single case of the rising anxiety and stress, which resulted from abortion [13].

Perceiving abortion as a problem affecting the somatic sphere only, without considering stress or the negative emotions, might have adverse consequences on the mental functioning of a woman. At the moment, most medical professionals are not fully prepared to deliver a multi-faceted care for a patient experiencing a miscarriage. The pregnancy loss that follows a miscarriage causes a huge trauma that can lead to numerous adverse consequences [14-16], caused by the unexpected miscarriage. Stress and anxiety happen to women experiencing a miscarriage, so a joint analysis of these two emotions is very important for maintaining good health in general [15].

\footnotetext{
${ }^{1}$ Independent Unit of Midwifery Skills, Medical University of Lublin, Poland

${ }^{2}$ Chair and Department of Endocrine Gynecology, Medical University of Lublin, Poland

${ }^{3}$ Midwifery Department, Gynecology and Nursing, Midwifery Department, Medical University of Lublin, Poland
} 


\section{STRESS AND MISCARRIAGE}

Stress (Greek: Stres, English: Stress) is defined as nonspecific response of the body to the influence of noxious stimuli, widely known as the stressors [16]. A Canadian scholar - Hans Selye - Professor at the Institute of Experimental Medicine and Surgery at the University of Montreal defined stress as the sum of all non-specific effects of various factors that may affect the system. Selye believes that biological stress is a nonspecific reaction of the body to any demands presented to it. Hence, it may evoke both positive emotions, like joy or satisfaction, as well as negative ones, like pain, fatigue, anger or shame $[16,17]$

A stress response that appears after a miscarriage as a result of numerous stress factors accompanying it, namely external noxious stimuli. According to Selye, an emergency situation triggers the defense mechanisms, to which he refers to as the "general adaptation syndrome" (General Adaption Syndrome - GAS). Adaptive syndrome consists of three stages:

1. Alarm reaction - there is both a shock and a shock counteracting phase. Due to the increased activity of the sympathetic nervous system and adrenals, the defense mechanisms grow stronger.

2. Resistance phase - the body is fighting the stressors, which leads to adverse consequences. It becomes clear that the body uses too much of its energy resources.

3. The third stage is related to exhaustion - occurs to an increased stimulation of the body, the appearance of anger and frustration, e.g., physiological disorders: sleep and a decrease of the total resistance, which leads to increased morbidity or interferes with the healing process.

Stress negatively affects female functioning in the society and it may also lead to the development of some serious medical conditions. Stress development can have a noticeable effect over the specific and nonspecific changes in the human body, affecting both the physiological and psychological aspect. Those changes affect behavior, ability to work and health condition. They do not occur simultaneously which means that they might be associated with both an acute and chronic stress $[8,18,19]$. Abortion is a sudden event accompanied by stress which might have a devastating effect on the female psyche [16].

Stress as an indicator of imbalance - emotional homeostasis of the body, indicates there is a problem of psychological nature, requiring some immediate assistance. In women that experienced a miscarriage, the stress-load might manifest itself by: temporary or permanent breaking of any social bonds, as well as some violent reactions to the situation. Women often display shock, denial, anger, frustration, guilt and helplessness. In case there is no professional help available immediately, a prolonged stressful disorder can disturb normal functioning, causing depression and even lead to suicidal thinking $[11,14]$.

\section{ANXIETY AND MISCARRIAGE}

Fear (Gr: Phobos, English: Anxiety) is defined as one of the most common human emotions. It tends to appear as a result of the increased feeling of an acute threat, the source of which remains unknown [20,21]. Anxiety can be defined as a process, in which an individual exposed to a psychologically uncomfortable situation prepares themselves for a defensive reaction that may take the form of a fight or avoidance. Research has shown that anxiety appears in the prenatal life between the 5th and 7th month of life and it accompanies humans throughout their lives [8]. Therefore, it can be assumed that anxiety is adaptive in nature and seeks to minimize the risks. In clinical practice, e.g. in case of trauma associated with miscarriage, anxiety can disaptative and harmful effect to health [22-24].

Cattell and Scheier define anxiety as a state in which similar emotional reactions occur, as a result of stimulation of the autonomic nervous system, regardless of the intensity and the stimuli that cause it. The idea of anxiety encompasses all internal conflicts and a persistent ability to react with fear, which is not affected by external conditions [25-28]. Cattell and Scheier's findings shed some new light on the issue of anxiety. Right now, scientists distinguish between characterological anxiety (i.e. pure anxiety) and anxiety as a reaction to stress or reactive/situational anxiety [29]. Studies have shown that high levels of anxiety as a trait and state anxiety can have a significant impact on human behavior and can make the confrontation with life's problems insurmountably difficult [27].

In 2013, a study conducted at the Department of MaternalFetal Medicine and Gynecology of the Medical University of Łódź looked at the levels of anxiety, depression and symptoms of post-traumatic stress disorder following a spontaneous abortion. The study included 40 women aged 18-39 who had experienced miscarriage. Studies show that abortion is a risk factor and it increases the level of anxiety in a particularly vulnerable group of women, deciding on the style of coping with stress based solely on emotions. Once again, these results confirmed that the women exposed to such adverse consequences of abortion are mainly those who had already experienced a pregnancy loss in the past [12]. Most people regard anxiety as useless and pointless. Meanwhile, fear is simply a natural reaction of the body to the negative external stimuli. Emotions physiologically shape the human psyche. However, one must not underestimate the fact that fear of excessive load can lead to negative consequences, including psycho-social functioning disorders and even depression [30].

\section{PREVENTION AND INTERVENTION}

American Psychiatric Association provides a definition of mental health in "Psychiatric Glossary". They define it as "simultaneous success in work, love and creativity combined with the ability to seek for mature and flexible solutions to conflicts between instincts, conscience, between the loved onesand reality [20]. Marmor and Pumpion-Mundlin define mental health as the relationships one has with the outside world, when the personality structure remains relatively stableand it is able to absorb environmental stress [12]. There is no universal definition of it, yet there is a consensus that mental health is a positive state of the person whose behavior is generally accepted by the environment [20]. In order to avoid the psychological consequences of pregnancy losses, 
a detailed analysis of stress and anxiety appearing in the course of a miscarriage is needed. Such an analysis should be conducted as early as possible, in order to recognize the first signs of disturbances in the area of mental functioning and extract a group of women most at risk of developing long-term consequences. An accurate assessment of the level of anxiety and stress will make it possible to implement effective preventive measures $[5,12]$.

However, one cannot predict how long will the recovery process and retaining emotional balance last [12]. The research done on a group of 124 women hospitalized at the Department of Perinatology and Gynecology at the University of Medical Sciences in Poznań showed that only $40 \%$ of pregnant women suffering from anxiety or depression received a correct diagnosis and only $5 \%$ to $20 \%$ of patients in this group received in time some form of psychological help and treatment [31]. One should note that the occurrence of anxiety often precedes depression. Research shows that anxiety and stress tend to occur simultaneously (the rate is approximately $80 \%$ ) [32]. Today, the interest in the problem of stress is focused on how to deal with it and on improving the quality of life and therefore the activity undertaken by an individual in light of stress factors. Unfortunately, people do not always manage to fight stress, which proves that they should receive professional help $[20,33]$.

The effectiveness of ways of coping with stress depends on a whole variety of factors, particularly the way the individual's nervous system operates. Factors like personality traits, one's intelligence, experience in dealing with stressful situations and the type of stressful situation experienced also count much [20]. The strategy for coping with stress is defined as a personal and permanent disposition to a particular struggle with stressful situations. The chosen way of dealing with stress depends on the type of stressful situation, the intensity of stress and other individual characteristics of the individual. The best way to free women from the trauma caused by abortion is to help them and their families understand these reactions and transform them into some constructive experience $[12,20]$.

Treating women who have experienced a miscarriage should not be limited to medical or nursing procedures. One should note that hospitalization usually causes an increase in emotional tension levels, isolation or loneliness. In case the treatment is limited to somatic procedures, some adverse effects may appear in women hospitalized due to abortion $[21,34]$.

The current knowledge about the emotions of women treated for abortion calls for a need of expanding the multidisciplinary care standards [26,27].

A study conducted in Finland looking at a group of women who have experienced miscarriage showed that one's 'obstetric history' may contribute to an increased risk of anxiety and stress or even lead to depression. A detailed analysis has shown that experiencing a miscarriage can lead to mood deterioration or even negatively affect one's general functioning, particularly in terms of mental health. The negative impact of abortion manifests itself through disturbances through mood disturbances, as well as an increased risk of anxiety disorders, stress and depression. Providing an individualized psychological support program to women of that group can reduce the risk of long-term psychological consequences [35].

Offering quick crisis intervention is what counts the most in helping women treated for abortion. The first day after the pregnancy loss proves critical for further psycho-social functioning. Medical assistance should be provided by an interdisciplinary team, including a doctor, a psychologist and a midwife. Patients should be asked to tell about their problem, express emotions and be informed about their rights. A woman has the right to bury the body of the child or its remains, regardless of how long the gestation lasted. The funeral of a lost child and the possibility of experiencing all the stages of grief can make the return of physical and emotional balance a much quicker process [5,36].

The woman who experienced a miscarriage should receive support from the people near her. Such women require huge understanding, since a miscarriage is an exceptional situation [37]. The type of anxiety or stress treatment should be carefully chosen, based on the type of the disorder. For a successful treatment of stress and anxiety, two basic methods should be taken into account: psychotherapy and pharmacotherapy. Today, both cognitive behavioral therapy (CBT) and interpersonal therapy seem to be the most relevant ones in the context of a psychotherapy. Among the psychotherapeutic methods of psychotherapy, there are both group and individual therapies, distinguished on the basis of the number of people participating in activities [38]. At Nagoya University Hospital in 2010, a pilot study was done in order to identify opportunities for psychological assistance to women who have experienced one or more miscarriages and have no children. The study group included patients of outpatient specialist care. The study was conducted using standardized tools, and the women were tested both before and after the application of CBT. It turned out that the attempt of psychological support using CBT can result in reducing the symptoms of anxiety, stress and depression, compared with those registered prior to therapy [8].

This study indicates that preventive measures and providing professional medical and psychological support, as well as a properly chosen method of treatment, can radically optimize this complex and sometimes lengthy process of returning the physical and mental balance in women hospitalized due to abortion [12]. An English study looking at a group of 13133 women who have experienced a miscarriage in the past showed that during the next pregnancy, the anxiety levels remained high, even if the course of pregnancy was proper. Also, studies have shown that giving birth to a healthy baby does not improve the mental condition or reduce symptoms of anxiety and depression in this group of women. This means, experiencing intense fear leaves a lasting mark on the female psyche. The results showed that experiencing a miscarriage at some point would always have an impact over the increase of anxiety or depression levels during subsequent pregnancies. In addition, experiencing anxiety or depression during in the prenatal period may increase the risk of postpartum depression. There is an overall agreement that preventing the onset of anxiety and depressive disorders can be of huge help, particularly to women who have experienced miscarriage already. Such an analysis should be based on a detailed analysis of the individual's obstetric history [26]. 
Various studies show that a correct diagnosis of high levels of anxiety or stress can prevent the occurrence of adverse psychological consequences of abortions. Eliminating the risk factors and the use of properly selected coping strategies can be beneficial for the treatment process $[32,33,36,37]$.

\section{CONCLUSIONS}

Abortion is accompanied by stress and a lot of negative emotions, such as, for example: anxiety, which can be exacerbated by the need for hospitalization and the need to implement the treatment. Negative emotions can damage women's cognitive resources depriving them of their confidence, they can exacerbate the sense of danger, lead to stress and hinder treatment.

Stress and anxiety levels in women treated due to abortion may help determine the characteristics of the group of women demanding individualized, multidisciplinary care, help identify courses of action psycho as well as contribute to the optimization of treatment.

\section{REFERENCES}

1. Rutkowska A, Kowalska A, Makara-Studzińska M, Kwaśniewska M Analiza struktury osobowości u kobiet w pierwszej ciąży prawidłowej i wysokiego ryzyka. Probl Psychiatr. 2011;12(4):420-7.

2. Bielan Z, Macha A, Stankowska I. Psychoseksualne konsekwencje straty w okresie ciąży i porodu. Seksuol Pol. 2010;8(1):41-6.

3. Boyce P, Condon JT, Ellwood DA. Pregnancy loss: a major life event affecting emotional health and well-being. Med J Aust. 2002;176:250-1.

4. Bubiak A, Bartnicki J, Knihnicka-Mercik Z. Psychologiczne aspekty utraty dziecka w okresie prenatalnym. Piel Zdr Publ. 2014;4(1):69-78.

5. Bręborowicz G. Krwawienia we wczesnej ciąży. Położnictwo. Podręcznik dla położnych i pielegniarek. Warszawa: Wydawnictwo Lekarskie PZWL; 2012. p. 212-3.

6. Słomko Z. Ginekologia. Warszawa: Wydawnictwo Lekarskie PZWL; 2008. p. 691-9.

7. Giannandrea S, Cerulli C, Anson E, Chaudron LH. Increased Risk for Postpartum Psychiatric Disorders Among Women with Past Pregnancy Loss. J Women's Health. 2012;22(9):760-6.

8. Nakano Y, Akechi T, Furukawa TA, Sugiura-Ogasawara M. Cognitive behavior therapy for psychological distress in patients with recurrent miscarriage. Psychol Res Behav Managem. 2013;6:37-43.

9. Medjedović V. Anxiety and Depression and Pregnant Women with Previous History of Spontaneous Abortion. Coll Antropol. 2014;(Suppl.1):225-8

10. Gopal M. Medical management of first trimestr pregnancy loss. In: Obstetric Evidence Based Guidelines. Wyd. 5. USA: Berghella Informa; 2009. p. 2015-9

11. Więckowska E. Stres jako wskaźnik zaburzenia równowagi emocjonalnej - sygnalizacja problemu. Zdr Publ. 2008;118(2):121-3.

12. Murlikewicz M, Sieroszewski P. Poziom depresji, lęku i objawów zaburzenia po stresie pourazowym w następstwie poronienia samoistnego. Perinatol Neonatol Ginekol. 2013;6(2):93-8.

13. Lewicka M, Wójcik M. Charakterystyka negatywnych emocji występujących u kobiet w ciąży wysokiego ryzyka. Eur J Med Technol. 2013;1(1):60-7.

14. Rutkowska A, Rolińska A, Kwaśniewski W, et al. Lęk - jako stan i jako cecha w ciąży prawidłowej i ciąży wysokiego ryzyka. Probl Psychiatr. 2011;12(1):56-9.
15. Słomko Z. Ginekologia. Warszawa: Wydawnictwo Lekarskie PZWL; 2008. p. 691-9.

16. Selye H. Stres okiełznany. Warszawa: PIW; 1978.

17. Toffol E, Koponen P, Partonen T. Miscarriage and mental health: Results of population-based studies. Psychiatr Res. 2013:151-8.

18. Dendana M. Messaoudi S, Hizem S, et al. Common polymorphisms in the P-selection gene in women with recurrent spontaneous. Gene. 2012;495(1):72-5.

19. Płotka A. Zdrowy styl życia psychicznego. Lublin: Wyd. NeuroCentrum; 2003.

20. Wrześniewski K. Style a trategie radzenia sobie ze stresem. In: I. Heszen-Niejodek, Z. Ratajczak (ed). Człowiek w sytuacji stresu. Katowice: Wyd. UŚ; 1996.

21. Rybakowski J. Zaburzenia lękowe w postaci fobii. In: S. Pużyński, J. Rybakowski, J. Wciórka. Psychiatria, Psychiatria Kliniczna. Wrocław: Elsevier Urban\&Partner; 2011. p. 382-94.

22. Wciórka J. Psychopatologia: objawy i zespoły zaburzeń. In: S. Pużyński, J. Rybakowski, J. Wciórka. Psychiatria, Psychiatria Kliniczna. Wrocław: Elsevier Urban\&Partner; 2010. p. 382-94.

23. Morley L, Shilito J, Tang T. Preventing recurrent miscarriage of unknown etiology. Obstet Gynaecol. 2013;15:99-105.

24. Blackmore RE, Côté-Arsenault D, Tang W, et al. Previous prenatal loss as a predictor of perinatal depression and anxiety. Br J Psychiatry. 2011;198:373-8.

25. Cheung C, Chan $\mathrm{Ch}, \mathrm{Ng}$ E. Stress and anxiety depression levels following first - trimestr miscarriage: a comparison between women who conceived naturally and women who conceived with assisted reproduction. Int J Obstet Gynecol. 2013;120:1090-7.

26. Łuczak-Wawrzyniak J, Czarnecka-Iwańczuk M, Bukowska A, Konofalska N. Wczesne i późne psychologiczne skutki utraty ciąży. Ginekol Pol. 2010;81:374-7.

27. Siek S. Wybrane metody badania osobowości. Warszawa: Wydawnictwo Teologii Katolickiej; 1993.

28. Sękowski A, Płudowska M. Niepokój egzystencjalny i lęk u osób o zróżnicowanym poziomie zdolności twórczych. Lublin: Wyd. Kul; 2011. p. 14.

29. Śliwak J. Niepokój a poziom altruizmu. Przegl Psychol. 2002;45(2):229.

30. Betts SK, Williams GM, Najman JM, Alati R. Maternal depressive anxious, and stress symptoms pregnancy predict internalizing problems in adolescence. Depression and Anxiety. 2014;31:9-18.

31. Watrowski R, Rhode A. Validation of the Polish version of the Hospital Anxiety and Depression Scale in three populations of gynecologic patients. Arch Med Sci. 2014;10(3):517-24.

32. Lamers F, van Oppen P, Comijs HC, et al. Comorbidity patterns of anxiety and depressive disorders in a large cohort study: the Netherlands Study of Depression and Anxiety (NESDA). Psychiatry. 2011;72:341-8.

33. Heszen-Niejodek I. Stres i radzenie sobie - główne kontrowersje. In: I. Heszen-Niejodek, Z. Ratajczak (ed). Człowiek w sytuacji stresu. Problemy teoretyczne i metodologiczne. Katowice: Wydawnictwo Uniwersytetu Śląskiego; 2000. p. 20-1.

34. Bielan Z, Macha A, Stankowska I. Psychoseksualne konsekwencje straty w okresie ciąży i porodu. Seksuol Pol. 2010;8(1):41-6.

35. Toffol E, Koponen P, Partonen T. Miscarriage and mental health: Results of two population - based studies. Psychiatry Res. 2013;205:151-8.

36. Heszen I, Sęk H. Wybrane psychologiczne aspekty ginekologii i położnictwa. Psychologia Zdrowia w wybranych dziedzinach medycyny. Psychologia Zdrowia. Warszawa: Wydawnictwo Naukowe PWN; 2012.

37. Faisal-Cury A. Huang H, Chan YF, Menezes PR. The Relationship Between Depressive/Anxiety Symptoms During Pregnancy/Postpartum and Sexual Life Decline after Delivery. JSM. 2013;10:1343-9.

38. Sokołowska M. Relacja psychoterapeutyczna w terapii poznawczobehawioralnej pacjentów z zaburzeniami osobowości. Psychoterap. 2013164(1):23-30.

\section{Corresponding author}

Mariola Kicia

Independent Practical Obstetric Skills Unit of Health Sciences Department, Medical University of Lublin

4/6 Staszica Str., 20-081 Lublin,

tel./fax: 81 448-68-40

E-mail: mariola.kicia@umlub.pl 